\title{
Inactivation of SARS-CoV-2 by Ozonated Glycerol
}

\author{
Yohei Takeda ${ }^{1,2} \cdot$ Dulamjav Jamsransuren $^{2} \cdot$ Yoshimasa Makita $^{3} \cdot$ Akihiro Kaneko $^{4} \cdot$ Sachiko Matsuda ${ }^{2} \cdot$ \\ Haruko Ogawa ${ }^{2} \cdot$ Hourei $^{5}{ }^{5}$ (i)
}

Received: 30 April 2021 / Accepted: 19 June 2021 / Published online: 26 June 2021

(c) The Author(s), under exclusive licence to Springer Science+Business Media, LLC, part of Springer Nature 2021

\begin{abstract}
We evaluated the SARS-CoV-2-inactivation activity of ozonated glycerol (OG). When a viral solution with $1 \%$ fetal bovine serum (FBS) was mixed with test solutions at a ratio of 1:19 and incubated for $20 \mathrm{~s}$, OG with ozone concentrations of over $1000 \mathrm{ppm}$ inactivated $\geq 94.38 \%$ of the virus. Extension of the reaction time to $1 \mathrm{~h}$ led to the inactivation of $\geq 99.82 \%$ of the virus (the viral titer was below the detection limit). Extension to $24 \mathrm{~h}$ resulted in concentrations over $200 \mathrm{ppm}$ OG inactivating $\geq 99.87 \%$ of the virus (the viral titers were below the detection limit). Next, viral solutions with 1, 20, and $40 \%$ FBS were mixed with test solutions at a ratio of 1:19 and incubated for $5 \mathrm{~min}$. Whereas the virucidal activity of $500 \mathrm{ppm}$ OG was very limited in the presence of 1\% FBS (79.47\% inactivation), it increased in the presence of 20 and $40 \%$ FBS (95.13 and $97.95 \%$ inactivation, respectively; the viral titers were not below the detection limit). Meanwhile, over 1000 ppm OG inactivated $\geq 99.44 \%$ of the virus regardless of the FBS concentration (the viral titers were below the detection limit). Extension of the reaction time to $1 \mathrm{~h}$ led to $500 \mathrm{ppm} \mathrm{OG}$ inactivating $\geq 99.91$ and $\geq 99.95 \%$ of the virus with 20 and $40 \%$ FBS, respectively (the viral titers were below the detection limit). These results suggested that OG might be useful as a virucidal agent against SARS-CoV-2.
\end{abstract}

Keywords Ozonated glycerol $\cdot$ Severe acute respiratory syndrome coronavirus $2 \cdot$ Antiviral material $\cdot$ Hand hygiene

\section{Introduction}

There has been a rapid worldwide increase in studies regarding control of the novel coronavirus disease 2019 (COVID19 ), caused by severe acute respiratory syndrome coronavirus 2 (SARS-CoV-2) (WHO, 2021a). Since the main infection route of SARS-CoV-2 is droplet transmission, appropriate implementation of measures against it is needed to prevent COVID-19 transmission. However, it is also possible to contract infections from the hands and environmental surfaces (Choi et al., 2021; Meyerowitz et al., 2021). The WHO recommends cleaning environmental surfaces and keeping hands clean, in addition to measures against droplet transmission (WHO, 2021b). Concomitantly, the need

\author{
Hourei Oh \\ ohoh@cc.osaka-dent.ac.jp \\ Yohei Takeda \\ ytakeda@obihiro.ac.jp \\ Dulamjav Jamsransuren \\ duuya.dj@gmail.com \\ Yoshimasa Makita \\ makita@cc.osaka-dent.ac.jp \\ Akihiro Kaneko \\ kaneko@ikegamihosp.jp \\ Sachiko Matsuda \\ chaka@obihiro.ac.jp \\ Haruko Ogawa \\ hogawa@obihiro.ac.jp
}

1 Research Center for Global Agromedicine, Obihiro University of Agriculture and Veterinary Medicine, 2-11 Inada, Obihiro, Hokkaido 080-8555, Japan

2 Department of Veterinary Medicine, Obihiro University of Agriculture and Veterinary Medicine, 2-11 Inada, Obihiro, Hokkaido 080-8555, Japan

3 Department of Chemistry, Osaka Dental University, 8-1 Kuzuha Hanazono Hirakata, Osaka 573-1121, Japan

4 Department of Oral Surgery, Ikegami General Hospital, 6-1-19 Ikegami Ootaku, Tokyo 146-8531, Japan

5 Center of Innovation in Dental Education, Osaka Dental University, 8-1 Kuzuha Hanazono Hirakata, Osaka 573-1121, Japan 
for antiviral agents for hand and environmental hygiene has been increasing. In this study, we focused on the biological activity of ozone. Ozone is a triatomic molecule consisting of 3 oxygen atoms, and has a short half-life, quickly converting into oxygen (Burns, 1997). Ozone is an oxidant that is highly corrosive to metals. High concentrations of ozone gas are harmful to humans and animals, and have been shown to impair the respiratory system when inhaled (Bartlett et al., 1974). However, low concentrations of ozone gas are not toxic, and an ozone and oxygen gas mixture has been used therapeutically (Bocci et al., 2011). Dissolution of ozone in water, creating ozonated water $(\mathrm{OW})$, has been reported to improve both the effectiveness and safety of ozone (Hirai et al., 2019). However, ozone in OW has a shorter half-life than ozone gas (Rice \& Gomez-Taylor, 1986). In particular, OW is known as a powerful inactivating agent against bacteria, fungi, protozoa, and viruses (Kim et al., 1999), and has been suggested to exert antimicrobial effects in running water (Nakamura et al., 2018). More recently, low concentrations of OW were shown to reduce viral infectivity upon exposure to SARS-CoV-2 for 1 min (Martins et al., 2021). In addition, it was reported that high ozone concentrations in OW rapidly inactivated SARS-CoV-2 (Inagaki et al., 2021).

As its name implies, ozonated glycerol (OG) is a glycerol gel containing ozone (Niinomi et al., 2004). More specifically, OG has been reported to have a long half-life (Niinomi et al., 2004), be safe for the skin, eyes, and oral mucosa (Fukui et al., 2015; Wang et al., 2011), as well as exert antibacterial (Niinomi et al., 2004; Fukui et al., 2014) and hemostatic (Sakai et al., 2014) effects.

In this study, we evaluated the ability of various concentrations of ozone in OG to inactivate SARS-CoV-2. Furthermore, we compared the viral-inactivating activity of OG in the presence of various fetal bovine serum (FBS) concentrations, which were used as a potentially interfering organic substance, and translated the obtained results for hand hygiene.

\section{Materials and Methods}

\section{Test Samples}

Glycerol (concentration $\geq 95 \%$ ) was purchased from Sakamoto Yakuhin Kogyo Co., Ltd. (Osaka, Japan). For the preparation of OG samples, glycerol was ozonated using an Ozonizer (Mediplus Co., Tokyo, Japan), which produces ozone from medical grade oxygen. The maximal ozone concentration in OG was $2000 \mathrm{ppm}$. Glycerol (undiluted) was used as the solvent control for OG (2000 ppm). Then, OG samples $(20,200,500$, and $1000 \mathrm{ppm})$ were prepared by diluting the prepared OG $(2000 \mathrm{ppm})$ with ultrapure water. Glycerol (100-times-, 10-times-, 4-times-, and 2-times-diluted) was also prepared by diluting glycerol with ultrapure water, and used as the solvent control for the OG sample $(20,200,500$, and $1000 \mathrm{ppm})$.

\section{Virus and Cells}

SARS-CoV-2 (JPN/TY/WK-521 strain) was kindly provided by the National Institute of Infectious Diseases (Tokyo, Japan). VeroE6/TMPRSS2 cells (cell number: JCRB1819) (Nao et al., 2019) were purchased from the Japanese Collection of Research Bioresources (Osaka, Japan). The virus growth medium (VGM) was Dulbecco's modified Eagle's medium (Nissui Pharmaceutical Co., Ltd., Tokyo, Japan) supplemented with $1 \%$ FBS, 2 mM L-glutamine (Fujifilm Wako Pure Chemical Co., Ltd., Osaka, Japan), $100 \mu \mathrm{g} / \mathrm{mL}$ kanamycin (Meiji Seika Pharma Co., Ltd., Tokyo, Japan), and $2 \mu \mathrm{g} / \mathrm{mL}$ amphotericin B (Bristol-Myers Squibb Co., New York, NY).

\section{Evaluation of Virucidal Activities of Test Samples}

SARS-CoV-2-containing VGM with a viral titer of $\sim 7.0$ $\log _{10} 50 \%$ tissue culture infective dose $\left(\mathrm{TCID}_{50}\right) / \mathrm{mL}$ was supplemented with 1,20 , or $40 \%$ (v/v) FBS and mixed with test samples at viral-to-test sample ratios of 1:19. These mixtures were incubated for $20 \mathrm{~s}$ to $24 \mathrm{~h}$ at $22{ }^{\circ} \mathrm{C}$ and then inoculated into cells cultured in VGM containing $10 \mathrm{mM}$ sodium thiosulfate, which quenches the ozone by reducing it. Then, the inoculated mixtures were diluted ten-fold in the cell culture medium (VGM) in the presence of sodium thiosulfate. After incubation for $3 \mathrm{~d}$ at $37^{\circ} \mathrm{C}$, the cytopathic effect was observed, and the viral titer $\left(\mathrm{TCID}_{50} / \mathrm{mL}\right)$ in each sample group was calculated using the Behrens-Kärber method (Kärber, 1931). Then the reduction in viral titer was calculated as $\log _{10} \mathrm{TCID}_{50} / \mathrm{mL}$ of the control group subtract $\log _{10} \mathrm{TCID}_{50} / \mathrm{mL}$ of the OG group. The means of multiple samples are presented in the Results section. The detection limit of the viral titer in each test sample group was determined based on the cytotoxicity of each test sample. The detection limit was set higher in the group treated with higher cytotoxicity test samples. As the 20 ppm OG sample did not show any cytotoxicity, the detection limit of the viral titer in the group treated with this sample was set to 1.25 $\log _{10} \mathrm{TCID}_{50} / \mathrm{mL}$, according to our viral titer calculation. Whereas, the rest of the OG samples $(200,500,1000$, and $2000 \mathrm{ppm}$ ) demonstrated cytotoxicity. The detection limit in the groups treated with these samples was set to $2.25 \log _{10}$ $\mathrm{TCID}_{50} / \mathrm{mL}$.

\section{Statistical Analysis}

The Student's $t$ test was performed to analyze the statistical significance of the differences in viral titer between the 
solvent control and OG groups. Statistical significance was set at $p<0.05$.

\section{Results}

\section{Evaluation of Virucidal Activity of Ozonated Glycerol}

First, we evaluated the SARS-CoV-2-inactivating activity of OG samples (ozone concentrations: 500-2000 ppm) after $20 \mathrm{~s}$ of reaction time. We mixed the $1 \%$ FBS-containing viral solution with either solvent control glycerol or OG samples at a viral-to-test solution ratio of 1:19. We observed that, whereas, the viral titer in the $500 \mathrm{ppm}$ OG group was comparable to that in the control group, the viral titers in the $1000 \mathrm{ppm}$ and $2000 \mathrm{ppm}$ OG-treated groups were lower than those of the control [OG (1000 ppm): $1.25 \log _{10}$ $\mathrm{TCID}_{50} / \mathrm{mL}$ reduction compared with the control: $94.38 \%$ virus inactivation; OG $(2000 \mathrm{ppm}): \geq 1.81 \log _{10} \mathrm{TCID}_{50} /$ $\mathrm{mL}$ reduction: $\geq 98.46 \%$ virus inactivation] (Fig. 1a). We subsequently evaluated the virucidal activities of OG samples (20-2000 ppm) after $1 \mathrm{~h}$ of reaction time. Whereas the viral titer in the $20 \mathrm{ppm}$ OG group was comparable to that in the control group, the 200 to 2000 ppm OG-treated groups showed concentration-dependent virucidal activity [OG (200 ppm): $0.94 \log _{10} \mathrm{TCID}_{50} / \mathrm{mL}$ reduction: $88.45 \%$ virus inactivation; OG (500 ppm): $1.56 \log _{10} \mathrm{TCID}_{50} / \mathrm{mL}$ reduction: $97.26 \%$ virus inactivation; $\mathrm{OG}(1000 \mathrm{ppm}): \geq 2.75 \log _{10}$ $\mathrm{TCID}_{50} / \mathrm{mL}$ reduction: $\geq 99.82 \%$ virus inactivation; OG (2000 ppm): $\geq 2.28 \log _{10} \mathrm{TCID}_{50} / \mathrm{mL}$ reduction: $\geq 99.58 \%$ virus inactivation]. We further found that the viral titers in the $1000 \mathrm{ppm}$ and $2000 \mathrm{ppm}$ OG groups were below the detection limit (Fig. 1b). After $24 \mathrm{~h}$ of reaction time, we noticed that the viral titer in the $20 \mathrm{ppm}$ OG group was comparable to that in the control group, whereas the viral titers in the 200 to $1000 \mathrm{ppm}$ OG-treated groups were below the detection limit [OG (200 ppm): $\geq 2.88 \log _{10}$ $\mathrm{TCID}_{50} / \mathrm{mL}$ reduction: $\geq 99.87 \%$ virus inactivation; OG (500 ppm): $\geq 2.81 \log _{10} \mathrm{TCID}_{50} / \mathrm{mL}$ reduction: $\geq 99.85 \%$ virus inactivation; OG (1000 ppm): $\geq 2.63 \log _{10} \mathrm{TCID}_{50} / \mathrm{mL}$ reduction: $\geq 99.76 \%$ virus inactivation]. As the viral titers in both the glycerol control, of which the virucidal activity is known (Cameron et al., 2000), and the 2000 ppm OG-treated groups were almost below the detection limit, we did not observe any statistically significant difference between these two groups (Fig. 1c).

\section{Impact of Fetal Bovine Serum Content in Viral Solution on Virucidal Activity of Ozonated Glycerol}

Next, we tested the virucidal activity of OG samples against SARS-CoV-2 solutions in different FBS concentrations (1, 20 , and $40 \%$ ). Viral solutions were mixed with either solvent control glycerol or OG samples at a viral-to-test solution ratio of $1: 19$. After $5 \mathrm{~min}$ of reaction time, we observed that the reduction in viral titer by the $500 \mathrm{ppm}$ OG samples was proportional to the FBS content in the viral solution (1\% FBS: $0.69 \log _{10} \mathrm{TCID}_{50} / \mathrm{mL}$ reduction compared with the control: $79.47 \%$ virus inactivation; $20 \%$ FBS: 1.31 $\log _{10} \mathrm{TCID}_{50} / \mathrm{mL}$ reduction: $95.13 \%$ virus inactivation; $40 \%$ FBS: $1.69 \log _{10} \mathrm{TCID}_{50} / \mathrm{mL}$ reduction: $97.95 \%$ virus inactivation). In contrast, the viral titers in the $1000 \mathrm{ppm}$ and
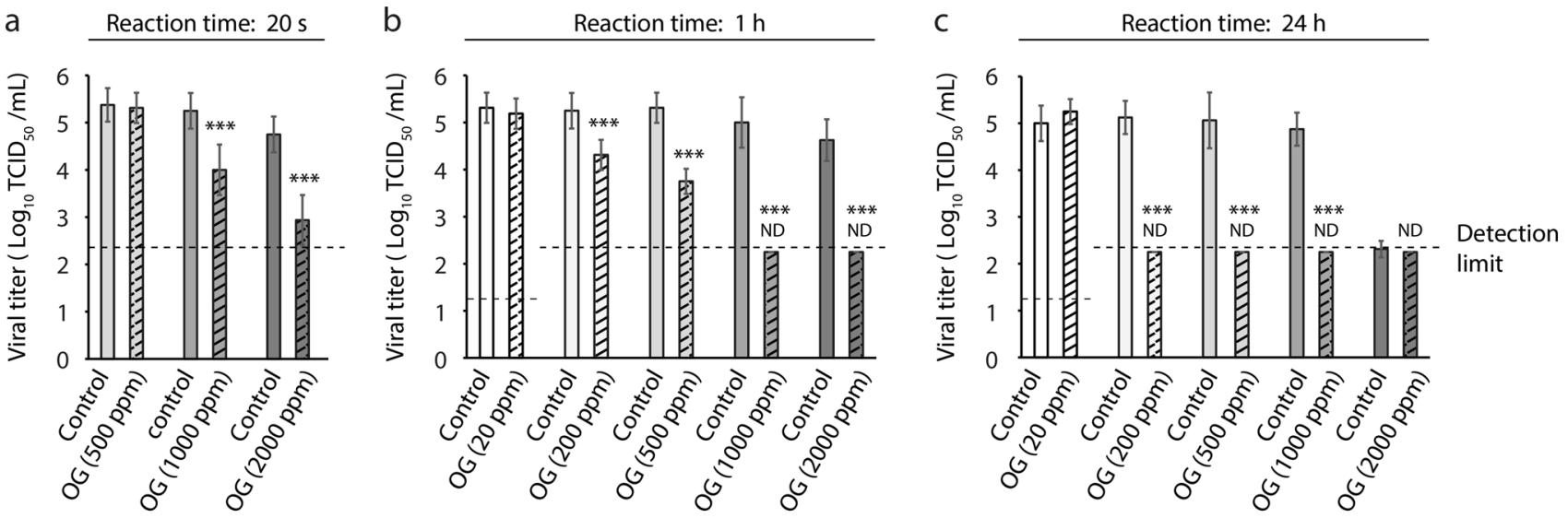

Fig. 1 Evaluation of virucidal activity of ozonated glycerol (OG). $(\mathbf{a}-\mathbf{c})$ Severe acute respiratory syndrome coronavirus 2 solution containing $1 \%$ fetal bovine serum was mixed with OG samples (ozone concentration: 20,200, 500,1000, and $2000 \mathrm{ppm}$ ) or solvent control glycerol at a viral-to-test sample ratio of 1:19. The viral titer of each reaction mixture was measured after $20 \mathrm{~s} \mathrm{(a),} 1 \mathrm{~h}(\mathbf{b})$, or $24 \mathrm{~h} \mathrm{(c)} \mathrm{reac-}$ tion time. Results are presented as the mean $\pm \mathrm{SD}$ ( $n=8$ per group).
The detection limits of the viral titer were $1.25 \log _{10} 50 \%$ tissue culture infective dose $\left(\mathrm{TCID}_{50}\right) / \mathrm{mL}$ in the $20 \mathrm{ppm}$ OG-treated groups, whereas it was $2.25 \log _{10} \mathrm{TCID}_{50} / \mathrm{mL}$ in the $200,500,1000$, and $2000 \mathrm{ppm}$ OG-treated groups. ND stands for not detected, indicating that the viral titer was below the detection limit. Student's $t$ test was performed to analyze the statistical significance between the solvent control and OG groups; *** $p<0.001$ 
2000 ppm OG-treated groups were below the detection limit regardless of the FBS content in the viral solution $(\geq 2.25$ $\log _{10} \mathrm{TCID}_{50} / \mathrm{mL}$ reduction: $\geq 99.44 \%$ virus inactivation) (Fig. 2a). We further found that after $1 \mathrm{~h}$ of reaction time, the viral titer in the $500 \mathrm{ppm}$ OG-treated groups was not below the detection limit when the viral solution contained $1 \%$ FBS $\left(1.50 \log _{10} \mathrm{TCID}_{50} / \mathrm{mL}\right.$ reduction: $96.84 \%$ virus inactivation). We noticed that the viral titer in this group was below the detection limit when it contained 20 or $40 \%$ FBS (20\% FBS: $\geq 3.06 \log _{10} \mathrm{TCID}_{50} / \mathrm{mL}$ reduction: $\geq 99.91 \%$ virus inactivation; $40 \% \mathrm{FBS}: \geq 3.31 \log _{10} \mathrm{TCID}_{50} / \mathrm{mL}$ reduction: $\geq 99.95 \%$ virus inactivation) (Fig. $2 b$ ).

\section{Discussion}

The mechanism of inactivation of viruses by ozone is known to involve the destruction of viral spikes, envelope proteins, and lipids through the oxidation of viral proteins, lipoproteins, lipids, glycolipids, and glycoproteins (Rowen \& Robins, 2020), resulting in potential inhibition of the attachment of the virus to the host receptor (Tizaoui, 2020). In the case of SARS-CoV-2 and other coronaviruses, the nucleocapsid is surrounded by an envelope consisting of a lipid bilayer, with the spike protein (S protein) being expressed on the surface of the viral particle. The $S$ protein consists of 2 subunits: the $\mathrm{S} 1$ and $\mathrm{S} 2$ subunits. SARS-CoV-2 has been reported to initiate invasion into host cells after binding of the $\mathrm{S} 1$ subunit to the viral receptor (ACE2) on the cell membrane. The $\mathrm{S}$ protein is then cleaved into $\mathrm{S} 1$ and $\mathrm{S} 2$ subunits by a protease, thought to be furin, derived from host cells. The $\mathrm{S} 2$ subunit is further cleaved and primed by transmembrane serine protease 2 (TMPRSS2), a serine protease on the surface of host cells, resulting in the fusion of the viral envelope with the host cell membrane (Hoffmann et al., 2020). Recently, ozone was proposed to act on the S protein of coronavirus, preventing membrane fusion with host cells (Manjunath et al., 2021).

OW has recently been shown to reduce the infectivity of SARS-CoV-2 following exposure of the virus to low concentrations of OW for 1 min (Martins et al., 2021). In addition, $10 \mathrm{ppm} \mathrm{OW}$, which is a high ozone concentration for OW, rapidly inactivates SARS-CoV-2 (Inagaki et al., 2020). While the ozone in OW is rapidly lost, OG maintains its bactericidal activity over a longer period. Almost no decrease was observed in its virucidal activity even when OG was left at $25{ }^{\circ} \mathrm{C}$ (room temperature) for 2 months after production (Niinomi et al., 2004). The viscosity of glycerol has been suggested to impede the release of ozone from OG into the air, and delay its decomposition owing to its stabilization by glycerol.

Disinfectants are generally affected by the presence of organic substances, such as blood and saliva (Kampf et al., 2005). In case the object to be sterilized contains a large amount of protein, such as blood, it is recommended to remove the protein by wiping or prewashing before exposure a

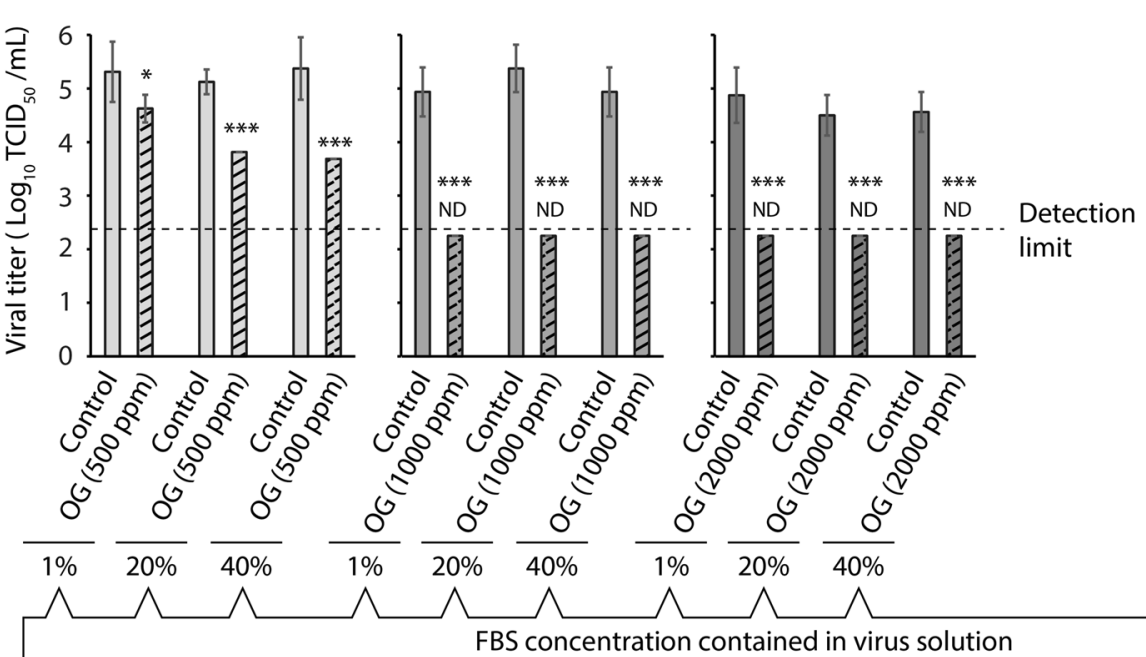

b Reaction time: $1 \mathrm{~h}$
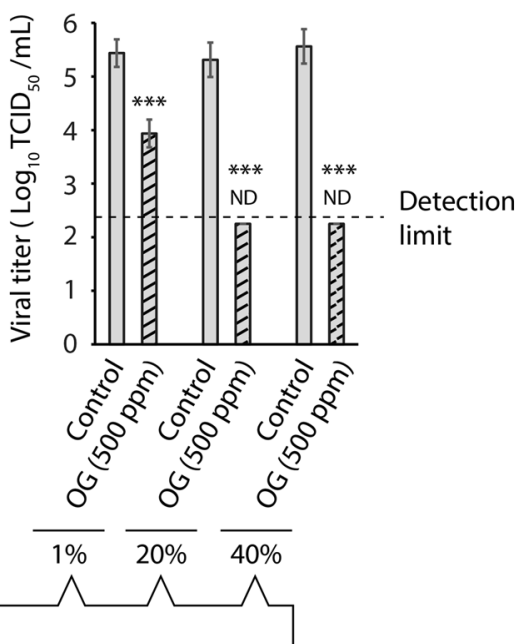

Fig. 2 Evaluation of the impact of fetal bovine serum (FBS) content in the viral solution on virucidal activity of ozonated glycerol (OG). $(\mathbf{a}, \mathbf{b})$ Severe acute respiratory syndrome coronavirus 2 solution containing 1, 20, or $40 \%$ FBS was mixed with OG samples (ozone concentration: 500, 1000, and $2000 \mathrm{ppm}$ ), or solvent control glycerol at a viral-to-test sample ratio of 1:19. The viral titer of each reaction mixture was measured after 5 min (a) or $1 \mathrm{~h}$ (b) reaction time. Results are indicated as the mean $\pm \mathrm{SD}$ ( $\mathrm{n}=8$ per group). The detection limit of the viral titer was $2.25 \log _{10} 50 \%$ tissue culture infective dose $\left(\mathrm{TCID}_{50}\right) / \mathrm{mL}$. ND stands for not detected, indicating that the viral titer was below the detection limit. Student's $t$ test was performed to analyze the statistical significance between the solvent control and OG groups; $* p<0.05, * * * p<0.001$ 
to OW (Hirai et al., 2019). In this study, we added excess FBS as an organic contaminant in the viral solution. We found that $\mathrm{OG}$ with high ozone concentrations strongly inactivated SARS-CoV-2 contaminated with $1-40 \%$ FBS. Notably, at high concentrations of 20 or $40 \%$ FBS, viral inactivation by $500 \mathrm{ppm}$ OG samples was stronger than that with $1 \%$ FBS. It has been shown that the oxidizing ability of ozone is improved when used in combination with iron, ultraviolet rays, and hydrogen peroxide (Aziz \& Amr, 2015). As the activity of ozone is known to be increased by activation factors such as iron ions contained in FBS, the inactivation activities of $\mathrm{OG}$ might have increased with increases in the concentration of FBS. As OG can contain much higher concentration of ozone than $\mathrm{OW}$, which has been previously shown to exert SARS-CoV-2-inactivation activity, a sufficient amount of ozone would have remained even after reaction with excess amounts of organic substances. Hence, such a high concentration of residual ozone might have shown potent virucidal activities through not only a single function but also an additive function with an activation factor in FBS. Saliva contains lactoferrin, which contains iron ions. Therefore, OG is expected to potentially have the same inactivation activity on SARS-CoV-2 coexisting with saliva on environmental surfaces as that observed in this experiment.

It has been reported that SARS-CoV-2 is active on most contactable surfaces (Wu et al., 2020). It has also been pointed out that SARS-CoV-2 might survive for $9 \mathrm{~h}$ on the skin (Hirose et al., 2020). Although the main route of SARS$\mathrm{CoV}-2$ infection is droplet transmission, it is also possible to contract the infection from hands and environmental surfaces (Choi et al., 2021; Meyerowitz et al., 2021). Therefore, healthcare professionals need to encourage handwashing procedures to achieve robust SARS-CoV-2 control measures during the COVID-19 pandemic (The Lancet, 2020). Specifically, disinfection with $80 \%$ ethanol for $15 \mathrm{~s}$ was shown to completely inactivate SARS-CoV-2 on the skin, demonstrating the importance of hand hygiene for SARS-CoV-2 (Hirose et al., 2020). Most recently, a disinfectant containing ethyl alcohol, chloroxylenol, and quaternary ammonium compounds has been reported to inactivate SARS-CoV-2 (Ijaz et al., 2020). However, these disinfectants have been shown to cause skin irritation, and as handwashing measures have now been strengthened, healthcare professionals were reported to exhibit increased skin irritation (Erdem et al., 2020; Guertler et al., 2020; Lan et al., 2020). Recent studies have shown that OW is less irritating to the skin than traditional disinfectants, raising interest in $\mathrm{OW}$ as an alternative handwashing treatment (Breidablik et al., 2019; Kashiwazaki et al., 2020). Likewise, OG is also less irritating to the skin and has a longer ozone half-life than OW (Fukui et al., 2015; Wang et al., 2011).

We believe that OG, which showed an antiviral effect on SARS-CoV-2 even in the presence of high concentrations of organic substances, is a good candidate for safe disinfection procedures. $\mathrm{OG}$ is slower to inactivate viruses than ethanol. Thus, at this point, it is difficult to use OG as a substitute for ethanol. However, OG is less harmful to the skin than ethanol, and its effects are sustainable. Therefore, applying OG to the hands after washing may prevent infectious viruses from subsequently attaching to the hands for a long time. OG is also less irritating to mucous membranes than ethanol. To further expand the use of OG, we are currently investigating its application to mucous membranes such as the nasal and oral cavities.

Acknowledgements We would like to thank Editage (www.editage. com) for English language editing.

Funding This work was supported by the Japanese Association for Dental Science, Sponsored Research 2020-A-1.

Data availability The datasets generated during and/or analyzed during the current study are available from the corresponding author on reasonable request.

\section{Declarations}

Conflicts of interest The authors declared no conflict of interest.

\section{References}

Aziz, H. A., \& Amr, S. S. A. (2015). Performance of combined ozone and Fenton process in treating different leachate concentrations. IAFOR Journal of Sustainability, Energy and the Environment, 2(1), 3-20.

Bartlett, D., Jr., Faulkner, C. S., 2nd., \& Cook, K. (1974). Effect of chronic ozone exposure on lung elasticity in young rats. Journal of Applied Physiology, 37(1), 92-96. https://doi.org/10.1152/jappl. 1974.37.1.92

Bocci, V., Zanardi, I., \& Travagli, V. (2011). Has oxygen-ozonetherapy a future in medicine? Journal of Experimental and Integrative Medicine, 1(1), 5-11.

Breidablik, H. J., Lysebo, D. E., Johannessen, L., Skare, Å., Andersen, J. R., \& Kleiven, O. T. (2019). Ozonized water as an alternative to alcohol-based hand disinfection. The Journal of Hospital Infection, 102(4), 419-424. https://doi.org/10.1016/j.jhin.2019.01.026

Burns, D. (1997). Early problems in the analysis and the determination of ozone. Fresenius' Journal of Analytical Chemistry, 357, 178-183. https://doi.org/10.1007/s002160050133

Cameron, P. U., Pagnon, J. C., van Baare, J., Reece, J. C., Vardaxis, N. J., \& Crowe, S. M. (2000). Efficacy and kinetics of glycerol inactivation of HIV-1 in split skin grafts. Journal of Medical Virology, 60(2), 182-188. https://doi.org/10.1002/(SICI)10969071(200002)60:2\%3c182::AID-JMV13\%3e3.0.CO;2-Y

Choi, H., Chatterjee, P., Coppin, J. D., Martel, J. A., Hwang, M., Jinadatha, C., \& Sharma, V. K. (2021). Current understanding of the surface contamination and contact transmission of SARSCoV-2 in healthcare settings. Environmental Chemistry Letters, 19, 1935-1944.

Erdem, Y., Altunay, I. K., Aksu Çerman, A., Inal, S., Ugurer, E., Sivaz, O., Kaya, H. E., Gulsunay, I. E., Sekerlisoy, G., Vural, O., \& Özkaya, E. (2020). The risk of hand eczema in healthcare workers during the COVID-19 pandemic: Do we need specific attention or 
prevention strategies? Contact Dermatitis, 83(5), 422-423. https:// doi.org/10.1111/cod.13632

Fukui, T., Masuno, K., Makita, Y., Fujiwara, S., Shiota, G., Imamura, Y., Shiba, A., \& Wang, P. L. (2015). Evaluation of oral mucosa irritation produced by ozone gel. Journal of Hard Tissue Biology, 24(1), 104-106. https://doi.org/10.2485/jhtb.24.104

Fukui, T., Masuno, K., Makita, Y., Fujiwara, S., Shiota, G., Imamura, Y., Shiba, A., \& Wang, P. (2014). Antimicrobial effects of ozone gel against periodontal bacteria. Journal of Hard Tissue Biology, 23(4), 445-448. https://doi.org/10.2485/jhtb.23.445

Guertler, A., Moellhoff, N., Schenck, T. L., Hagen, C. S., Kendziora, B., Giunta, R. E., French, L. E., \& Reinholz, M. (2020). Onset of occupational hand eczema among healthcare workers during the SARS-CoV-2 pandemic: Comparing a single surgical site with a COVID-19 intensive care unit. Contact Dermatitis, 83(2), 108-114. https://doi.org/10.1111/cod.13618

Hirai, K., Ando, N., Komada, H., Sounai, A., Murakami, A., \& Nakayama, H. (2019). Investigation of the effective concentration of ozonated water for disinfection in the presence of protein contaminants. Biocontrol Science, 24(3), 155-160. https://doi.org/ 10.4265/bio.24.155

Hirose, R., Ikegaya, H., Naito, Y., Watanabe, N., Yoshida, T., Bandou, R., Daidoji, T., Itoh, Y., \& Nakaya, T. (2020). Survival of SARS$\mathrm{CoV}-2$ and influenza virus on the human skin: Importance of hand hygiene in COVID-19. Clinical Infectious Diseases. https://doi. org/10.1093/cid/ciaa1517

Hoffmann, M., Kleine-Weber, H., Schroeder, S., Krüger, N., Herrler, T., Erichsen, S., Schiergens, T. S., Herrler, G., Wu, N. H., Nitsche, A., Müller, M. A., Drosten, C., \& Pöhlmann, S. (2020). SARSCoV-2 cell entry depends on ACE2 and TMPRSS 2 and is blocked by a clinically proven protease inhibitor. Cell, 181(2), 271-280.e8. https://doi.org/10.1016/j.cell.2020.02.052

Ijaz, M. K., Whitehead, K., Srinivasan, V., McKinney, J., Rubino, J. R., Ripley, M., Jones, C., Nims, R. W., \& Charlesworth, B. (2020). Microbicidal actives with virucidal efficacy against SARS-CoV-2. American Journal of Infection Control, 48(8), 972-973. https:// doi.org/10.1016/j.ajic.2020.05.015

Inagaki, H., Saito, A., Sudaryatma, P. E., Sugiyama, H., Okabayashi, T., \& Shouichi, F. (2021). Rapid inactivation of SARS-CoV-2 with ozonated water. Ozone Science \& Engineering, 43(3), 208212. https://doi.org/10.1080/01919512.2021.1889318

Kampf, G., Grotheer, D., \& Steinmann, J. (2005). Efficacy of three ethanol-based hand rubs against feline calicivirus, a surrogate virus for norovirus. The Journal of Hospital Infection, 60(2), 144-149. https://doi.org/10.1016/j.jhin.2004.12.005

Kärber, G. (1931). Beitrag zur kollektiven Behandlung pharmakologischer Reihenversuche. Naunyn-Schmiedebergs Archiv Für Experimentelle Pathologie Und Pharmakologie, 162, 480-483. https:// doi.org/10.1007/BF01863914

Kashiwazaki, J., Nakamura, K., Hara, Y., Harada, R., Wada, I., \& Kanemitsu, K. (2020). Evaluation of the cytotoxicity of various hand disinfectants and ozonated water to human keratinocytes in a cultured epidermal model. Advances in Skin \& Wound Care, 33(6), 313-318. https://doi.org/10.1097/01.ASW.0000658592. 51430.ea

Kim, J. G., Yousef, A. E., \& Dave, S. (1999). Application of ozone for enhancing the microbiological safety and quality of foods: A review. Journal of Food Protection, 62(9), 1071-1087. https://doi. org/10.4315/0362-028x-62.9.1071

Lan, J., Song, Z., Miao, X., Li, H., Li, Y., Dong, L., Yang, J., An, X., Zhang, Y., Yang, L., Zhou, N., Yang, L., Li, J., Cao, J., Wang, J., $\&$ Tao, J. (2020). Skin damage among health care workers managing coronavirus disease-2019. Journal of the American Academy of Dermatology, 82(5), 1215-1216. https://doi.org/10.1016/j.jaad. 2020.03 .014
Manjunath, S. N., Sakar, M., Katapadi, M., \& Geetha Balakrishna, R. (2021). Recent case studies on the use of ozone to combat coronavirus: Problems and perspectives. Environmental Technology \& Innovation, 21, 101313. https://doi.org/10.1016/j.eti.2020.101313

Martins, R. B., Castro, I. A., Pontelli, M., Souza, J. P., Lima, T. M., Melo, S. R., Siqueira, J. P. Z., Caetano, M. H., Arruda, E., \& de Almeida, M. T. G. (2021). SARS-CoV-2 inactivation by ozonated water: a preliminary alternative for environmental disinfection. Ozone Science \& Engineering, 43(2), 108-111. https://doi.org/ 10.1080/01919512.2020.1842998

Meyerowitz, E. A., Richterman, A., Gandhi, R. T., \& Sax, P. E. (2021). Transmission of SARS-CoV-2: A review of viral, host, and environmental factors. Annals of Internal Medicine, 174(1), 69-79. https://doi.org/10.7326/M20-5008

Nakamura, K., Saito, K., Kashiwazaki, J., Aoyagi, T., Arai, K., Hara, Y., Kobari, S., Mori, H., Ohashi, K., Takano, Y., Kaku, M., \& Kanemitsu, K. (2018). Evaluation of ozonated water using ASTM E1174 for standardized testing of handwash formulations for healthcare personnel. The Journal of Hospital Infection, 100(2), 211-213. https://doi.org/10.1016/j.jhin.2018.02.009

Nao, N., Sato, K., Yamagishi, J., Tahara, M., Nakatsu, Y., Seki, F., Katoh, H., Ohnuma, A., Shirogane, Y., Hayashi, M., Suzuki, T., Kikuta, H., Nishimura, H., \& Takeda, M. (2019). Consensus and variations in cell line specificity among human metapneumovirus strains. PLoS ONE, 14(4), e0215822. https://doi.org/10.1371/ journal.pone.0215822

Niinomi, K., Kanaishi, A., \& Akihiko, S. (2004). The bactericidal effects of ozone gel. The Journal of Showa University Dental Society, 24(2), 103-109.

Rice, R. G., \& Gomez-Taylor, M. (1986). Occurrence of by-products of strong oxidants reacting with drinking water contaminants-scope of the problem. Environmental Health Perspectives, 69, 31-44. https://doi.org/10.1289/ehp.866931

Rowen, R. J., \& Robins, H. (2020). A plausible "penny" costing effective treatment for corona virus: Ozone therapy. Journal of Infectious Diseases and Epidemiology, 6(2), 113.

Sakai, D., Makita, Y., Masuno, K., Fujiwara, S., Okazaki, J., \& Wang, P. (2014). Local hemostatic effect of aqueous ozone in cutting wound surface. Journal of Hard Tissue Biology, 23(2), 245-248. https://doi.org/10.2485/jhtb.23.245

The Lancet. (2020). COVID-19: Protecting health-care workers. Lancet (london, England), 395(10228), 922. https://doi.org/10.1016/ S0140-6736(20)30644-9

Tizaoui, C. (2020). Ozone: a potential oxidant for COVID-19 virus (SARS-CoV-2). Ozone Science \& Engineering, 42(5), 378-385. https://doi.org/10.1080/01919512.2020.1795614

Wang, P. L., Shiota, G., \& Shiba, A. (2011). Safety evaluation of ozone gel for skin and eye on animal experiments. Journal of Hard Tissue Biology, 20(4), 313-318. https://doi.org/10.2485/jhtb.20.313

World Health Organization. WHO Coronavirus (COVID-19) Dashboard. Retrieved April 20, 2021a, from http://covid19.who.int/

World Health Organization. (2020, October 20). Coronavirus disease (COVID-19): How is it transmitted? Retrieved April 20, 2021b, from https://www.who.int/news-room/q-a-detail/coronavirusdisease-covid-19-how-is-it-transmitted

Wu, S., Wang, Y., Jin, X., Tian, J., Liu, J., \& Mao, Y. (2020). Environmental contamination by SARS-CoV-2 in a designated hospital for coronavirus disease 2019. American Journal of Infection Control, 48(8), 910-914. https://doi.org/10.1016/j.ajic.2020.05.003

Publisher's Note Springer Nature remains neutral with regard to jurisdictional claims in published maps and institutional affiliations. 